\title{
Effectiveness of different footbath solutions in the treatment of digital dermatitis in dairy cows
}

\author{
M. H. M. Speijers, ${ }^{\star 1}$ L. G. Baird, ${ }^{\star}$ G. A. Finney, ${ }^{\star}$ J. McBride, ${ }^{\star}$ D. J. Kilpatrick,† D. N. Logue,‡ \\ and N. E. O’Connell§ \\ *Agri-Food and Biosciences Institute (AFBI), Agriculture Branch, Hillsborough, Northern Ireland, UK BT26 6DR \\ †Agri-Food and Biosciences Institute, Biometrics Department, Belfast, Northern Ireland, UK BT9 5PX \\ ‡Faculty of Veterinary Medicine, University of Glasgow, UK G61 1QH \\ $\S S c h o o l$ of Biological Sciences, Medical Biology Centre, Queens University Belfast, Belfast, Northern Ireland, UK BT9 7BL
}

\begin{abstract}
Three experiments were conducted to test the effectiveness of different footbath solutions and regimens in the treatment of digital dermatitis (DD) in dairy cows. During the study, groups of cows walked through allocated footbath solutions after milking on 4 consecutive occasions. All cows were scored weekly for DD lesion stage on the hind feet during milking. A "transition grade" was assigned on the basis of whether the DD lesions improved (1) or deteriorated or did not improve (0) from week to week. This grade per cow was averaged for all cows in the group. In experiment 1, 118 cows were allocated to 1 of 3 footbath treatments for 5 wk: (1) $5 \% \mathrm{CuSO}_{4}$ each week, (2) $2 \% \mathrm{ClO}^{-}$each week, or (3) no footbath (control). The mean transition grade, and proportion of cows without DD lesions at the end of the trial were significantly higher for treatment 1 above $(0.36,0.13$, and 0.11 , respectively; standard error of the difference, SED $=0.057$ ). In experiment 2, 117 cows were allocated to 1 of 4 footbath treatment regimens for 8 wk: (1) $5 \% \mathrm{CuSO}_{4}$ each week, (2) $2 \% \mathrm{CuSO}_{4}$ each week, (3) $5 \% \mathrm{CuSO}_{4}$ each fortnight, or (4) $2 \% \mathrm{CuSO}_{4}$ each fortnight. For welfare reasons, cows allocated to the weekly and fortnightly footbath regimens had an average prevalence of $>60 \%$ and $\leq 25 \%$ active DD at the start of the trial, respectively. Significantly more cows had no DD lesions (0.53 vs. 0.36, respectively; $\mathrm{SED}=0.049)$, and the mean transition grade of DD lesions was higher in the $5 \%$ compared with the $2 \%$ weekly $\mathrm{CuSO}_{4}$ treatment (0.52 vs. 0.38 , respectively; SED $=0.066)$. Similarly, significantly more cows had no DD lesions in the $5 \%$ compared with the $2 \%$ fortnightly $\mathrm{CuSO}_{4}$ treatments (0.64 vs. 0.47, respectively; SED = 0.049). In experiment 3, 95 cows were allocated to 1 of 3 footbath treatments: (1) each week alternating 5\% $\mathrm{CuSO}_{4}$ with $10 \%$ salt water, (2) each week alternating
\end{abstract}

Received May 25, 2010.

Accepted August 26, 2010.

${ }^{1}$ Corresponding author: Mari.Speijers@afbini.gov.uk
$5 \% \mathrm{CuSO}_{4}$ with water, or (3) $5 \% \mathrm{CuSO}_{4}$ each fortnight (control). After $10 \mathrm{wk}$, more cows had no DD in the salt water treatment than in the control treatment $(0.35$ vs. 0.26, respectively; SED $=0.038)$, but levels of active lesions were higher for this treatment than in the other 2 treatments $(0.17,0.00$, and 0.13 , respectively; SED $=0.029$. Treatment did not affect mean transition grade of DD lesions. In conclusion, $\mathrm{CuSO}_{4}$ was the only footbath solution that was consistently effective for treatment of DD. In cases when DD prevalence was high, a footbath each week using $5 \% \mathrm{CuSO}_{4}$ was the most effective treatment.

Key words: copper sulfate, dairy cow, digital dermatitis, footbath regime

\section{INTRODUCTION}

Digital dermatitis (DD) is a worldwide problem in dairy herds that accounts for approximately 20 to $25 \%$ of all cases of lameness (Laven, 2003). It commonly manifests as lesions to the skin of the foot, particularly just above the heel, and it is thought to be caused by bacterial infection. It is not only a serious welfare issue in dairy herds, but it has serious financial implications. For example, the estimated cost of each case of DD varies between $£ 75$ and $£ 82$ in the United Kingdom (Esslemont, 2005). Often, the most practical solution for controlling DD is group topical therapy (i.e., footbaths); however, for this to be successful, an effective antibacterial product needs to be used. Antibiotic (Laven and Proven, 2000; Stevančević et al., 2009) and formalin (Laven and Hunt, 2002; Holzhauer et al., 2008b) footbath solutions were effective in reducing or controlling the problem or both, but neither can be recommended for use in footbaths. This is because antibiotics are expensive and not currently licensed for use as a dairy cow footbath treatment in the European Union; further, legislative restrictions on the sales of milk after antibiotic treatment exist (Laven and Logue, 2006). Formalin is toxic (Mitchell and Law, 1984) and carcinogenic (IARC, 2006) to animals and humans. 
Therefore, alternative effective footbath solutions are required.

Copper sulfate is commonly used as a nonantibiotic footbath solution for dairy cows. It was effective in reducing DD lesions when used at concentrations of 2 to $8 \%$ (Laven and Hunt, 2002; Stevančević et al., 2009), but anecdotal reports indicate that $\mathrm{CuSO}_{4}$ was not effective in reducing DD lesions in all cases (Blowey and Sharp, 1988; Nutter and Moffitt, 1990; RodriguezLainz et al., 1996). Concerns exist that copper may accumulate in the soil when footbath solutions are mixed with manure waste and disposed of by land application. This could have long-term toxic effects on the environment and on human health (Salam and El-Fadel, 2008). Therefore, efforts must be made to maximize effectiveness and minimize waste in terms of $\mathrm{CuSO}_{4}$ footbath solution use. Alternative footbath strategies that feature increased intervals between footbaths, reduced $\mathrm{CuSO}_{4}$ concentrations within footbath solutions, or footbath solutions that contain no $\mathrm{CuSO}_{4}$ at all should be considered.

A cheap alternative footbath solution could involve filling the footbath with circulation cleaner from the milking parlor wash cycle. Some farmers have this pumped directly to their footbaths (Blowey, 2007). Hypochlorite, commonly known as bleach, is often used in the final rinse of the parlor wash cycle. To date, information on the efficacy of $\mathrm{ClO}^{-}$as a footbath solution has not been properly substantiated. It is believed to clean claws and was effective in the treatment of DD lesions in one study when used as a $1 \%$ footbath solution daily for $30 \mathrm{~d}$ after surgical cleansing of lesions (da Silva et al., 2005).

The aim of this study was to compare the effectiveness of several footbath regimens and solutions in the treatment of DD in lactating dairy cows. This involved comparing $\mathrm{ClO}^{-}$and $\mathrm{CuSO}_{4}$ solutions and assessing the effectiveness of different concentrations of $\mathrm{CuSO}_{4}$ solutions and the effectiveness of a footbath using $\mathrm{CuSO}_{4}$ solutions at different time intervals.

\section{MATERIALS AND METHODS}

\section{Animals and Management}

Three studies were conducted to examine the effectiveness of different footbath solutions and regimens in the treatment of DD in lactating dairy cattle. These studies were conducted using the dairy herd at the Agri-Food and Biosciences Institute (Hillsborough, Northern Ireland) during the winter of 2008. Animals were housed in freestalls with a concrete base fitted with rubber or pasture mats, and bedded with sawdust thrice weekly. The freestall:cow ratio was $\geq 1: 1$ at all times, meeting the recommendations set by FAWC (1997). Solid concrete alleyway floors with occasional slats were scraped at least 4 times daily using an automated system. Cows were milked twice daily using a 50-stall rotary parlor. The cows used were allocated to nutritional studies and a range of diets was fed. Overall, the concentrate to forage ratio (DM basis) varied from 60:40 to 20:80. The forage component comprised 100 to $60 \%$ grass silage, with up to $40 \%$ corn silage. Animals had free access to water at all times.

All procedures were carried out under the 1986 Animals (Scientific Procedures) Act, and with the permission of the Agri-Food and Biosciences Institute Ethical Review Committee. All animals in the herd were examined for lameness-causing conditions by an experienced stockman on a regular basis and, if necessary, feet were trimmed or treated or both. For severe DD and other painful and contagious hoof problems, this required topical treatment with antibiotic aerosol spray containing $2.45 \% \mathrm{wt} / \mathrm{wt}$ chlortetracycline hydrochloride EP (CEVA Animal Health Ltd., Chesham, UK). Two to eight cows were treated per treatment group over the experimental period, but overall, the effect on DD control and treatment was minimal for these treatments.

\section{Footbath Regimen and Solutions}

During the study period, the cows walked through the allocated footbath solution after 4 consecutive milkings weekly $(\mathrm{X} 4 / \mathbf{1 W})$ or fortnightly $(\mathrm{X} 4 / \mathbf{2 W})$ depending on their allocated treatment. Before walking through the treatment footbath, the cows walked through a prerinse footbath filled with water. The footbaths used were $207 \mathrm{~cm}$ long $\times 79 \mathrm{~cm}$ wide $\times 22 \mathrm{~cm}$ high, and filled to a volume of $270 \mathrm{~L}$. The prerinse and treatment footbaths were approximately $125 \mathrm{~cm}$ apart.

Footbath solutions were changed after no more than 200 cows passed through the footbath, or within $24 \mathrm{~h}$ (if fewer than 200 cows walked through). The chemicals used for the experimental footbath solutions were as follows: $\mathrm{CuSO}_{4}$ pentahydrate $25 \%$ (EPA Reg. No. 56576-1, DSM Nutritional Products UK Ltd., Belfast, UK), sodium $\mathrm{ClO}^{-}$(Red Label Hypochlorite, Kilco, Lockerbie, UK), and salt (Ineos Enterprises Ltd., Runcorn, UK). To prepare the footbath solutions, each chemical was measured into a container before pouring into the footbath where water was added to a depth of $16.5 \mathrm{~cm}(270 \mathrm{~L})$ and mixed thoroughly.

\section{Experimental Treatments and Design}

Experiment 1. The experiment started in October 2008 when all cows in the herd had been housed (entirely or partially) for 2 wk. Lactating cows ( $\mathrm{n}=$ 
Table 1. Number of cows in the experimental treatments, and their mean live weight, numbers of lactations, DIM, and average milk yield at the start of each experiment ${ }^{1}$

\begin{tabular}{lccccc}
\hline Treatment $^{2}$ & $\mathrm{n}$ & $\begin{array}{c}\text { Live weight } \\
(\mathrm{kg})\end{array}$ & $\begin{array}{c}\text { Lactation } \\
\text { number }\end{array}$ & DIM & $\begin{array}{c}\text { Milk yield } \\
(\mathrm{kg})\end{array}$ \\
\hline Experiment 1 & & & & & \\
$\mathrm{CuSO}_{4} 5 \%(\mathrm{X} 4 / 1 \mathrm{~W})$ & 37 & $591(70.0)$ & $3(1.8)$ & $102(105.8)$ & $25.4(18.91)$ \\
$\mathrm{ClO}^{-}$2\% (X4/1W) & 37 & $589(75.4)$ & $3(1.4)$ & $117(113.5)$ & $24.2(16.95)$ \\
$\quad$ Control & 39 & $584(69.3)$ & $3(1.6)$ & $105(102.9)$ & $25.8(18.08)$ \\
Experiment 2 & & & & & \\
$\mathrm{CuSO}_{4} 5 \%(\mathrm{X} 4 / 1 \mathrm{~W})$ & 36 & $601(70.3)$ & $3(1.6)$ & $125(110.6)$ & $30.4(9.71)$ \\
$\mathrm{CuSO}_{4} 2 \%(\mathrm{X} 4 / 1 \mathrm{~W})$ & 29 & $575(131.6)$ & $3(1.5)$ & $102(97.7)$ & $30.2(10.68)$ \\
$\mathrm{CuSO}_{4} 5 \%(\mathrm{X} 4 / 2 \mathrm{~W})$ & 18 & $598(82.9)$ & $3(1.8)$ & $118(97.9)$ & $30.8(10.49)$ \\
$\mathrm{CuSO}_{4} 2 \%(\mathrm{X} 4 / 2 \mathrm{~W})$ & 19 & $616(62.1)$ & $3(1.9)$ & $131(109.2)$ & $26.8(7.39)$ \\
Experiment 3 & & & & & \\
$\quad$ Salt water & 28 & $622(75.7)$ & $3(1.4)$ & $87(40.4)$ & $36.3(8.78)$ \\
Tap water & 28 & $643(74.3)$ & $3(1.5)$ & $88(37.5)$ & $34.4(11.49)$ \\
Control & 29 & $611(71.4)$ & $3(1.6)$ & $90(43.3)$ & $35.7(8.85)$ \\
\hline
\end{tabular}

${ }^{1}$ Standard deviation given in brackets

${ }^{2}$ In experiments 1 and 2, treatments were as follows: footbath with $5 \%$ or $2 \%$ copper sulfate $\left(\mathrm{CuSO}_{4} 5 \%\right)$ or $2 \%$ hypochlorite applied after 4 consecutive milkings weekly $(\mathrm{X} 4 / 1 \mathrm{~W})$ or fortnightly $(\mathrm{X} 4 / 2 \mathrm{~W})$. Control = no footbath. In experiment 3: salt water = alternating footbaths of $5 \% \mathrm{CuSO}_{4}$ and salt water footbath on 4 consecutive milkings weekly: tap water = alternating footbaths of $5 \% \mathrm{CuSO}_{4}$ and tap water footbath on 4 consecutive milkings weekly; control $=5 \% \mathrm{CuSO}_{4}$ footbath on 4 consecutive milkings fortnightly.

118) that did not suffer from heel horn erosion, that was clearly visible, were selected from the herd and allocated to 1 of 3 treatments over a 5 -wk period: (1) the $\mathrm{X} 4 / 1 \mathrm{~W}$ footbath with $5 \% \mathrm{CuSO}_{4}(\mathrm{n}=40),(2)$ the $\mathrm{X} 4 / 1 \mathrm{~W}$ footbath with $2 \% \mathrm{ClO}^{-}(\mathrm{n}=39)$, or (3) no footbath (control; $\mathrm{n}=39$ ). More than $95 \%$ of the cows were of $100 \%$ Holstein-Friesian genotype. The animals were balanced across treatments for ongoing nutritional treatment, breed type, parity, DIM, milk yield, worst DD lesion score on either of the hind feet, BW, and BCS where possible. The number of cows in the experimental treatments and their mean BW, number of parities, DIM, and average milk yield at the start of the study (for this experiment, and for experiments 2 and 3) are in Table 1.

Experiment 2. Experiment 2 started in mid-November 2008, immediately after experiment 1 had finished. With the exception of 1 cow, the same group of lactating cows $(\mathrm{n}=117)$ that was used in experiment 1 was also used in experiment 2 . The animals were allocated to 1 of 4 treatment regimens for 8 wk: (1) the X4/1W footbath with $5 \% \mathrm{CuSO}_{4}(\mathrm{n}=39),(2)$ the $\mathrm{X} 4 / 1 \mathrm{~W}$ footbath with $2 \% \mathrm{CuSO}_{4}(\mathrm{n}=39)$, (3) the $\mathrm{X} 4 / 2 \mathrm{~W}$ footbath with $5 \% \mathrm{CuSO}_{4}(\mathrm{n}=19)$, or (4) the X4/2W footbath with $2 \% \mathrm{CuSO}_{4}(\mathrm{n}=20)$. Due to welfare concerns, cows that had been on the $\mathrm{ClO}^{-}$or control footbath treatments in experiment 1 were allocated to the weekly footbath regimen because of the high prevalence of active DD lesions $(>60 \%)$ at the start of experiment 2 , and cows that had been on the $\mathrm{CuSO}_{4}$ footbath treatment in experiment 1 were allocated to a fortnightly footbath because they had a lower prevalence of active DD lesions at the start of experiment $2(\leq 25 \%)$. Thus, as shown in Table 1, the numbers in the $\mathrm{X} 4 / 2 \mathrm{~W} 5 \%$ and $2 \% \mathrm{CuSO}_{4}$ footbath treatment groups were roughly half of that in the $\mathrm{X} 4 / 1 \mathrm{~W} 5 \%$ and $2 \% \mathrm{CuSO}_{4}$ footbath treatment groups. The animals were balanced across the weekly or fortnightly treatments as described earlier where possible.

Experiment 3. Experiment 3 started in January 2009 and lasted 10 wk. Only lactating cows $(\mathrm{n}=95)$ were used, and included 60 cows carried over from the previous studies $(115 \pm 2.3 \mathrm{DIM})$, and 35 cows that had calved in the preceding 2-mo period (44 \pm 3.8 DIM). They were allocated, as in experiment 1 , to 1 of 3 treatments: (1) the $\mathrm{X} 4 / 1 \mathrm{~W}$ footbath, which alternated between $5 \% \mathrm{CuSO}_{4}$ for 1 wk and $10 \%$ salt water $(\mathrm{NaCl})$ every other week $(\mathrm{n}=32),(2)$ the $\mathrm{X} 4 / 1 \mathrm{~W}$ footbath, which alternated between $5 \% \mathrm{CuSO}_{4}$ for $1 \mathrm{wk}$ and tap water every other week $(\mathrm{n}=32)$, or (3) the $\mathrm{X} 4 / 2 \mathrm{~W}$ footbath with $5 \% \mathrm{CuSO}_{4}$ ( $\mathrm{n}=31$; control). The animals were balanced for ongoing experiment, parity, DIM, milk yield, DD lesion score, BW, and BCS where possible.

\section{Data Collection}

The same procedures for data collection were used in all experiments. Cows were examined in the milking parlor immediately after milking on a weekly basis. The hind feet were washed using medium-pressure tap water before examination. Dermatitis was scored on both hind feet of all animals using a 5-point nominal scale developed by Döpfer et al. (1997), which takes into account the stage of DD lesion development (Table 2). A flashlight was used to ensure adequate light for scoring, 
Table 2. Scoring system for classification of digital dermatitis (DD) lesions ${ }^{1}$

\begin{tabular}{ll}
\hline $\begin{array}{l}\text { DD } \\
\text { score }\end{array}$ & Description \\
\hline M0 & No lesion \\
M1 & Early stage lesion up to $2 \mathrm{~cm}$ in diameter, generally not painful \\
M2 & Classical ulcerative stage with a diameter $>2 \mathrm{~cm}$, and often very painful upon touch \\
M3 & Healing stage, whereby the lesion is covered by a scab \\
M4 & Chronic stage of lesion, characterized by dyskeratosis or proliferation of the surface, generally not painful upon touch \\
\hline
\end{tabular}

${ }^{1}$ Developed by Döpfer et al. (1997).

and scores were recorded by a second person. Number, size (greatest diameter of lesions to the nearest $0.5 \mathrm{~cm}$ ), and color (red or not) of DD lesions on each hind foot were recorded. In cases with more than 1 lesion on a hind foot, the most active prominent stage of DD lesion was recorded.

\section{Statistical Analysis}

For the purpose of analysis, cows with early or acute classical ulcerative stage DD lesions (M1 + M2) on at least 1 hind foot were defined as cows having active DD lesions.

To determine the degree of healing, the transitions of DD lesions were defined as binomial data: For each cow that had DD lesions, the lesions were scored as "healed" when lesions were improving on both hind feet, and as "not healed" when either or both hind feet had lesions that were getting worse or not improving from week to week. This grade was then used to obtain means for each treatment group.

Five cows (experiment 1) and 15 cows (experiment 2) were omitted from the analysis for a range of reasons, which included either receiving the wrong treatment, being dried off, or dying from causes unrelated to the study.

All statistical analyses were carried out using the statistical package GenStat 12 (VSN International Ltd., Hemel Hempstead, UK). The data were analyzed using general estimating equation analysis with a binomial error distribution and an ante-dependence covariance structure of 1 between the time points (weeks). Data are presented as means \pm standard error of the difference (SED) unless otherwise stated. Significance is represented using $P<0.05$. Percentages of cows with active lesions for the different treatments are shown graphically.

\section{RESULTS}

\section{Foot Health and Characteristics of Lesions}

Most DD lesions were a single lesion of each foot and most cows with lesions had lesions on both hind feet
(65\% of cases). The size of an early-stage lesion (M1) was $1.2 \pm 0.03 \mathrm{~cm}$, and for an acute classical ulcerative stage (M2), it was $2.5 \pm 0.02 \mathrm{~cm}$. The sizes of a healing (M3) and chronic-stage (M4) lesion were $2.0 \pm 0.03$ $\mathrm{cm}$ and $3.0 \pm 0.10 \mathrm{~cm}$, respectively. The majority of DD lesions ranged in color from pink to creamy, yellow, black, or gray. Very few cows had lesions with obvious red coloring in either of the studies (7 to 8\%). About $4.5 \%$ of the DD lesions in the classical ulcerative stage (M2) had an obvious red coloring, displaying typical strawberry-like lesions.

Experiment 1. The distributions of the 5 different DD lesion stages on both feet of the cows for the different footbath treatments at the start and end of the trial are in Table 3. At the start of the trial treatments did not differ in the overall presence or absence of DD lesions. Some differences were found between the treatments for the separate DD lesion stages M1 to M4 due to the necessity of allocating the cows on the basis of their worst DD score $(\mathrm{M} 2>\mathrm{M} 1>\mathrm{M} 4>\mathrm{M} 3)$ on either of their hind feet. At the end of the study more cows had no DD and lesions in the healing stage (M3) and fewer cows with active lesions (M1 and M2) for the $\mathrm{CuSO}_{4}$ treatment compared with the hypochlorite and the control treatments $(P<0.05)$. On the other hand, more cows had chronic stage lesions (M4) in the $\mathrm{CuSO}_{4}$ treatment compared with the $\mathrm{ClO}^{-}$and the control treatments $(P<0.05)$. The only difference found between the $\mathrm{X} 4 / 1 \mathrm{~W} 2 \% \mathrm{ClO}^{-}$and control treatment was that more cows had early stage DD lesions (M1) for the control treatment compared with the $\mathrm{ClO}^{-}$treatment at the end of the treatment period $(P<0.05$; Table $3)$.

The proportion of cows that had DD lesions following normal healing transitions was $0.36,0.13$, and 0.11 for $\mathrm{X} 4 / 1 \mathrm{~W} 5 \% \mathrm{CuSO}_{4}, \mathrm{X} 4 / 1 \mathrm{~W} 2 \% \mathrm{ClO}^{-}$and control treatment groups, respectively $(\mathrm{SED}=0.057 ; P<$ 0.05). Overall, the $\mathrm{CuSO}_{4}$ treatment group had better average healing transitions of DD lesions than the other 2 groups $(P<0.05)$. No treatment differences were found for proportion of cows with DD lesions remaining absent (M0), with $0.32,0.26$ and 0.26 for $\mathrm{X} 4 / 1 \mathrm{~W}$ $5 \% \mathrm{CuSO}_{4}, \mathrm{X} 4 / 1 \mathrm{~W} 2 \% \mathrm{ClO}^{-}$and control treatment groups, respectively $(\mathrm{SED}=0.055 ; P>0.05)$. 


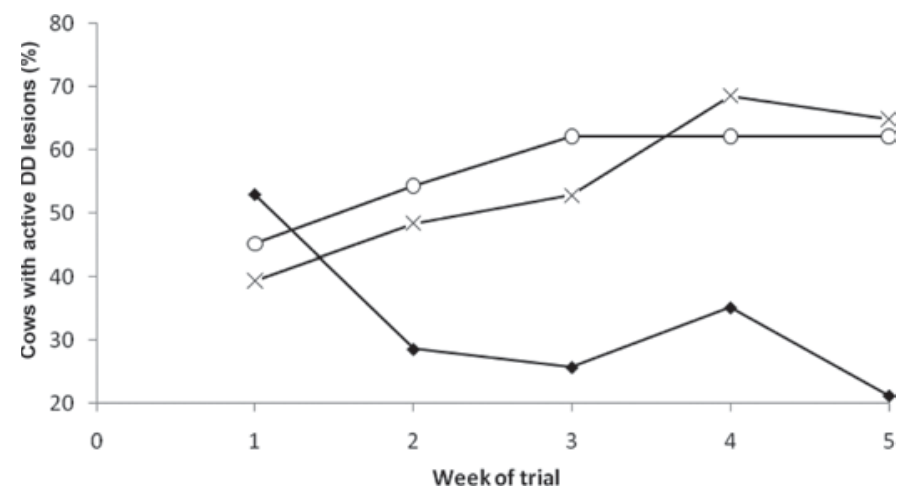

Figure 1. Percentage of cows with active digital dermatitis (DD) lesions (DD score in at least 1 hind foot) for weekly $5 \% \mathrm{CuSO}_{4}(\bullet ; \mathrm{n}$ $=37)$ and $2 \% \mathrm{ClO}^{-}(\mathrm{O} ; \mathrm{n}=37)$ footbath compared with no footbath $(\times ; \mathrm{n}=39)$ in experiment 1.

The active lesions (M1 and M2) over the experimental period for the different footbath treatments are in Figure 1. The number of cows in either the $\mathrm{ClO}^{-}$or control groups with active lesions increased steadily over the study period, whereas the number of cows with active DD lesions decreased in the X4/1W 5\% copper sulfate treatment.

Experiment 2. The distributions of the 5 different DD lesion stages in the cows for the weekly $5 \%$ and $2 \% \mathrm{CuSO}_{4}$ footbath treatments at the start and end of the trial are in Table 4. At the start of the trial no difference was observed between the treatments in the overall presence or absence of DD lesions. At the end of the study more cows had no DD in the X4/1W $5 \%$ $\mathrm{CuSO}_{4}$ treatment than in the $\mathrm{X} 4 / 1 \mathrm{~W} 2 \% \mathrm{CuSO}_{4}$ treatment $(P<0.05)$. The proportion of cows that had DD lesions following normal healing transition was higher for the $5 \%$ compared with the $2 \% \mathrm{CuSO}_{4}$ treatment (0.52 vs. 0.38 , respectively; $\mathrm{SED}=0.066 ; P<0.05)$. No treatment difference existed for proportion of cows with DD lesions remaining absent (M0), with 0.27 and 0.19 for $\mathrm{X} 4 / 1 \mathrm{~W} 5 \% \mathrm{CuSO}_{4}$ and $\mathrm{X} 4 / 1 \mathrm{~W} 2 \% \mathrm{CuSO}_{4}$, respectively $(\mathrm{SED}=0.051 ; P>0.05)$.

At the start of the trial no difference was observed between the fortnightly $(\mathrm{X} 4 / 2 \mathrm{~W}) 5 \%$ and $2 \% \mathrm{CuSO}_{4}$ footbathing treatments in the presence or absence of DD lesions, although some differences existed between the treatments for the separate DD lesion stages M3 and M4 (Table 5). At the end of the study more cows had no DD and fewer cows had early stage (M1) and chronic stage lesions (M4) for the $\mathrm{X} 4 / 2 \mathrm{~W} 5 \% \mathrm{CuSO}_{4}$ treatment compared with $\mathrm{X} 4 / 2 \mathrm{~W} 2 \% \mathrm{CuSO}_{4}(P<0.05$; Table 5). More cows had healing stage lesions (M3) in the $2 \% \mathrm{CuSO}_{4}$ treatment compared with the $5 \% \mathrm{CuSO}_{4}$ treatment of similar magnitude as that found at the start.

Treatment did not affect overall healing transitions of DD lesions; the proportion of cows that had DD lesions following normal healing transition was 0.41 and 0.36 for the $5 \%$ and $2 \% \mathrm{CuSO}_{4}$ treatment groups, respectively ( $\mathrm{SED}=0.066 ; P>0.05)$. Treatment did not affect proportion of cows with DD lesions remaining absent (M0), with 0.44 and 0.34 for $\mathrm{X} 4 / 2 \mathrm{~W} 5 \% \mathrm{CuSO}_{4}$

Table 3. Proportional distribution of digital dermatitis (DD) lesion scores in hind feet in the different treatment groups at the start and end of experiment 1

\begin{tabular}{lcccc}
\hline & \multicolumn{3}{c}{ Treatment $^{2}$} \\
\cline { 2 - 3 } DD stage $^{1}$ & $\mathrm{CuSO}_{4} 5 \%$ & $\mathrm{ClO}^{-} 2 \%$ & Control & SED $^{3}$ \\
\hline M0 (no lesion) & & & & \\
Start & 0.35 & 0.42 & 0.45 & 0.051 \\
End & $0.45^{\mathrm{b}}$ & $0.24^{\mathrm{a}}$ & $0.30^{\mathrm{a}}$ & 0.051 \\
M1 (active) & 0.12 & 0.06 & 0.06 & 0.031 \\
Start & $0.09^{\mathrm{a}}$ & $0.16^{\mathrm{b}}$ & $0.27^{\mathrm{c}}$ & 0.031 \\
End & $0.44^{\mathrm{b}}$ & $0.39^{\mathrm{ab}}$ & $0.33^{\mathrm{a}}$ & 0.052 \\
M2 (active) & $0.12^{\mathrm{a}}$ & $0.46^{\mathrm{b}}$ & $0.43^{\mathrm{b}}$ & 0.052 \\
Start & $0.15^{\mathrm{ab}}$ & $0.19^{\mathrm{b}}$ & $0.09^{\mathrm{a}}$ & 0.040 \\
End & $0.30^{\mathrm{b}}$ & $0.08^{\mathrm{a}}$ & $0.08^{\mathrm{a}}$ & 0.040 \\
M3 (healing) & & $0.06^{\mathrm{ab}}$ & $0.12^{\mathrm{b}}$ & 0.031 \\
Start & $0.06^{\mathrm{a}}$ & $0.11^{\mathrm{a}}$ & $0.05^{\mathrm{a}}$ & 0.031 \\
End & $0.30^{\mathrm{b}}$ & & & \\
M4 (chronic) & Start & & & \\
End & & & & \\
\hline
\end{tabular}

${ }^{\mathrm{a}-\mathrm{c}}$ Means within a row with different superscripts differ $(P<0.05)$.

${ }^{1} \mathrm{DD}$ stages: $\mathrm{M} 0=$ no lesion in both hind feet; $\mathrm{M} 1=$ early stage; $\mathrm{M} 2=$ classical ulcerative stage; $\mathrm{M} 3=$ healing stage; M4 = chronic stage. M1 to M4 = lesions in at least 1 hind foot.

${ }^{2}$ Treatments: $\mathrm{CuSO}_{4} 5 \%=5 \% \mathrm{CuSO}_{4}$ footbath on 4 consecutive milkings weekly $(\mathrm{n}=37) ; \mathrm{ClO}^{-} 2 \%=2 \%$ $\mathrm{ClO}^{-}$footbath on 4 consecutive milkings weekly $(\mathrm{n}=37)$; Control $=$ no footbath $(\mathrm{n}=39)$.

${ }^{3}$ Standard error of the difference. 
Table 4. Proportional distribution of digital dermatitis (DD) lesion scores in hind feet in cows on weekly 5 or $2 \%$ copper sulfate footbath treatments at the start and end of experiment 2

\begin{tabular}{lccc}
\hline & \multicolumn{2}{c}{ Treatment $^{2}$} \\
\cline { 2 - 3 } DD stage $^{1}$ & $\mathrm{CuSO}_{4} 5 \%$ & $\mathrm{CuSO}_{4} 2 \%$ & \\
\hline M0 (no lesion) & & & \\
$\quad$ Start & 0.29 & 0.24 & 0.049 \\
$\quad$ End & $0.53^{\mathrm{b}}$ & $0.36^{\mathrm{a}}$ & 0.049 \\
M1 (active) & & & \\
$\quad$ Start & 0.20 & 0.21 & 0.030 \\
End & 0.03 & 0.00 & 0.030 \\
M2 (active) & 0.49 & 0.45 & 0.047 \\
Start & 0.10 & 0.18 & 0.047 \\
End & 0.06 & 0.07 & 0.049 \\
M3 (healing) & 0.43 & 0.46 & 0.049 \\
Start & & & \\
End & 0.09 & 0.10 & 0.023 \\
M4 (chronic) & 0 & 0 & 0.023 \\
$\quad$ Start & & & \\
End & & & \\
\hline
\end{tabular}

${ }^{\mathrm{a}, \mathrm{b}}$ Means within a row with different superscripts differ $(P<0.05)$.

${ }^{1}$ DD stages: $\mathrm{M} 0=$ no lesion in both hind feet; M1 = early stage; M2 $=$ classical ulcerative stage; $\mathrm{M} 3=$ healing stage; $\mathrm{M} 4=$ chronic stage. M1 to M4 = lesions in at least 1 hind foot.

${ }^{2}$ Treatments: $\mathrm{CuSO}_{4} 5 \%=5 \% \mathrm{CuSO}_{4}$ footbath on 4 consecutive milkings weekly $(\mathrm{n}=36) ; \mathrm{CuSO}_{4} 2 \%=2 \% \mathrm{CuSO}_{4}$ footbath on 4 consecutive milkings weekly $(\mathrm{n}=29)$.

${ }^{3}$ Standard error of the difference.

and $\mathrm{X} 4 / 2 \mathrm{~W} 2 \% \mathrm{CuSO}_{4}$, respectively $(\mathrm{SED}=0.051 ; P$ $>0.05)$.

The active DD lesions (M1 and M2) over the experimental period for the $2 \mathrm{X} 4 / 1 \mathrm{~W}$ treatments are in Figure 2a. The number of cows with active lesions decreased over the study period for both treatments, but it decreased faster in the $\mathrm{X} 4 / 1 \mathrm{~W} 5 \% \mathrm{CuSO}_{4}$ treatment. Similarly the percentage of cows with early (M1) or classical ulcerative stage (M2) DD lesions in at least 1 hind foot for the different $\mathrm{X} 4 / 2 \mathrm{~W}$ footbath treatments are in Figure $2 \mathrm{~b}$. At the start and at the end of the study the prevalence was similar between both treatments. In the intervening period (wk 3 to 5 ) prevalence was lower in the $5 \%$ fortnightly $\mathrm{CuSO}_{4}$ treatment, but this treatment had a more clearly defined saw tooth pattern.

Experiment 3. At the start of the study differences existed between the treatments in absence of DD lesions (M0), with more cows on the salt water treatment with no DD lesions than cows on the water-only treatment $(P<0.05$; Table 6$)$. No difference was found between treatments for the ulcerative DD lesion stages (M2) and healing stage lesions (M3). During this experiment early-stage DD lesions occurred sporadically and only during the first 6 wk. On only 1 occasion was a M4 lesion observed in the salt water treatment at the start of the experiment. At the end of the study the proportion of cows with no DD was higher in the salt water treatment than in the control treatment $(P<0.05)$ and similar to the water treatment $(P<0.05$; Table $6)$. Moreover, at the end, fewer cows had healing stage lesions (M3) in the salt water treatment compared with control and water treatments $(P<0.05)$, but more cows had acute classical ulcerative stage lesions (M2) compared with the water treatment $(P<0.05)$.

Treatment did not affect overall healing transitions of DD lesions; the proportion of cows that had DD lesions following normal healing transition was $0.65,0.71$, and 0.70 for the salt water, water, and control treatment groups, respectively $(\mathrm{SED}=0.049 ; P>0.05$ ). Treatment did not affect the proportion of cows with DD lesions remaining absent (M0; 0.13, 0.17, and 0.13 for salt water, water, and control treatment groups, respectively; $\mathrm{SED}=0.034 ; P>0.05$ ).

The percentage of cows with active DD lesions (M1 and M2) over the experimental period for the different footbath treatments is in Figure 3. All the footbath treatments displayed a saw tooth pattern to some extent, with the lowest prevalence occurring after the weeks that $\mathrm{CuSO}_{4}$ treatment was applied.

\section{DISCUSSION}

\section{Description of Digital Dermatitis}

Digital dermatitis remains the leading cause of infectious lameness in dairy cows, even though it was first

Table 5. Distribution of digital dermatitis (DD) lesion scores in hind feet in cows on fortnightly 5 or $2 \%$ copper sulfate footbath treatments at the start and end of experiment 2

\begin{tabular}{llll}
\hline & \multicolumn{2}{c}{ Treatment $^{2}$} & \\
\cline { 2 - 3 } DD stage $^{1}$ & $\mathrm{CuSO}_{4} 5 \%$ & $\mathrm{CuSO}_{4} 2 \%$ & $\mathrm{SED}^{3}$ \\
\hline M0 (no lesion) & & & \\
Start & 0.47 & 0.47 & 0.049 \\
$\quad$ End & $0.64^{\mathrm{b}}$ & $0.47^{\mathrm{a}}$ & 0.049 \\
M1 (active) & & & \\
$\quad$ Start & 0.13 & 0.11 & 0.030 \\
$\quad$ End & $0.00^{\mathrm{a}}$ & $0.07^{\mathrm{b}}$ & 0.030 \\
M2 (active) & 0.07 & 0.11 & 0.047 \\
$\quad$ Start & 0.07 & 0.07 & 0.047 \\
End & $0.20^{\mathrm{a}}$ & $0.32^{\mathrm{b}}$ & 0.049 \\
M3 (healing) & $0.29^{\mathrm{a}}$ & $0.40^{\mathrm{b}}$ & 0.049 \\
$\quad$ Start & & & \\
End & $0.33^{\mathrm{b}}$ & $0.26^{\mathrm{a}}$ & 0.023 \\
M4 (chronic) & $0.00^{\mathrm{a}}$ & $0.07^{\mathrm{b}}$ & 0.023 \\
$\quad$ Start & & \\
End & &
\end{tabular}

${ }^{\mathrm{a}, \mathrm{b}}$ Means within a row with different superscripts differ $(P<0.05)$.

${ }^{1}$ DD stages: $\mathrm{M} 0=$ no lesion in both hind feet; $\mathrm{M} 1=$ early stage; $\mathrm{M} 2$ = classical ulcerative stage; $\mathrm{M} 3=$ healing stage; $\mathrm{M} 4=$ chronic stage. M1 to M4 = lesions in at least 1 hind foot.

${ }^{2}$ Treatments: $\mathrm{CuSO}_{4} 5 \%=5 \% \mathrm{CuSO}_{4}$ footbath on 4 consecutive milkings fortnightly $(\mathrm{n}=19)$; $\mathrm{CuSO}_{4} 2 \%=2 \% \mathrm{CuSO}_{4}$ footbath on 4 consecutive milkings fortnightly $(\mathrm{n}=19)$.

${ }^{3}$ Standard error of the difference. 
a)

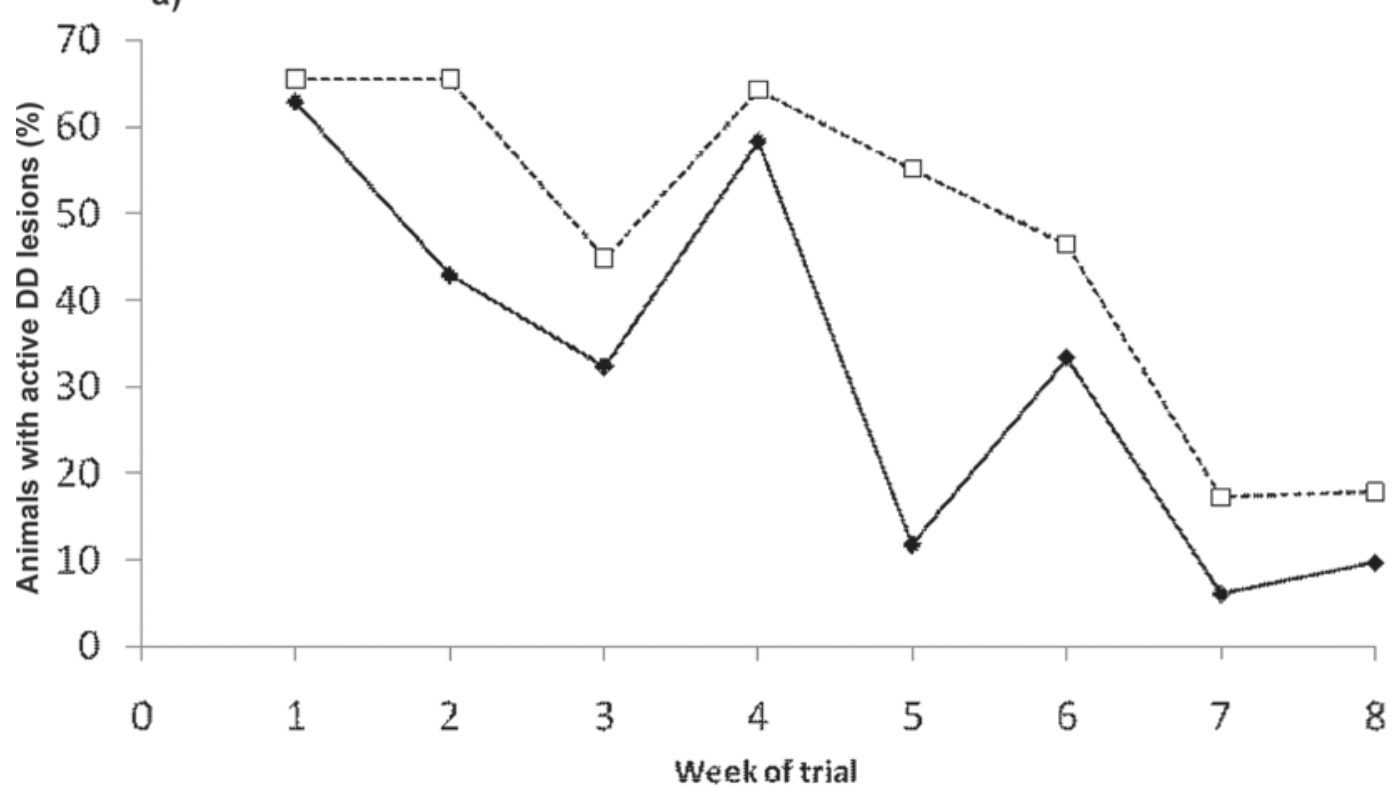

b)

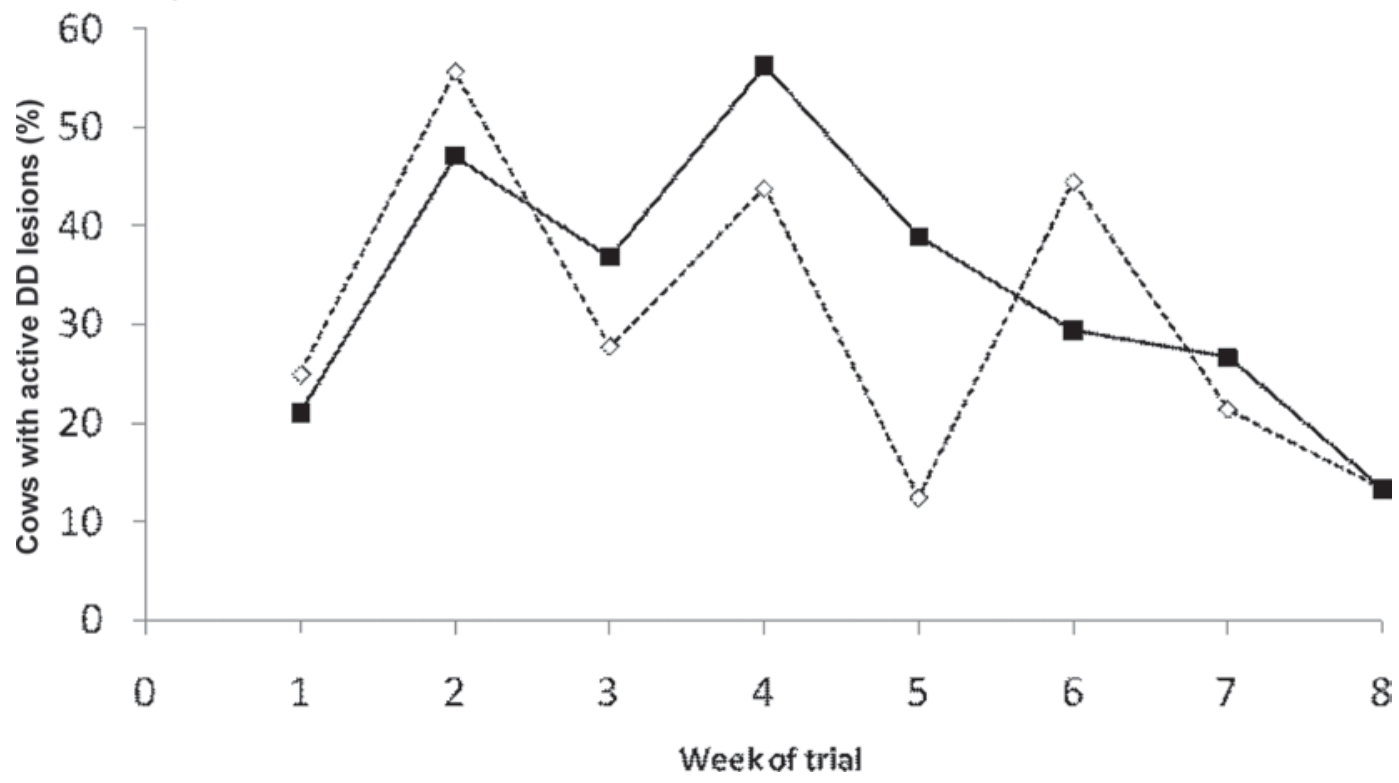

Figure 2. (a) Percentage of cows with active digital dermatitis (DD) lesions (DD score in at least 1 hind foot) for weekly $5 \%$ ( $\bullet$; $=36$ ) and $2 \% \mathrm{CuSO}_{4}(\square ; \mathrm{n}=29)$ footbath in experiment 2. (b) Percentage of cows with active DD lesions (DD score in at least 1 hind foot) for fortnightly $5 \%(\diamond ; \mathrm{n}=18)$ and $2 \% \mathrm{CuSO}_{4}(\mathbf{\square} ; \mathrm{n}=19)$ footbath in experiment 2.

reported more than $30 \mathrm{yr}$ ago. At the start of the study $59 \%$ of cows were affected by DD on at least 1 of their feet. This is consistent with Holzhauer et al. (2008a), who reported a similar prevalence of DD in cows housed during winter. Furthermore, during the first 5 wk of the current study the incidence of DD increased by $5 \% /$ wk without regular footbaths, which supported the estimated $6 \%$ risk of an "active infection" per week reported by Holzhauer et al. (2008a).
The data presented is based on an evaluation of the hind feet alone. The majority of DD lesions (80 to 90\%) occur in the hind feet of cows (Nutter and Moffitt, 1990; Read and Walker, 1998; Vink, 2006), which means that scoring hind feet should result in a respectable representation of the overall DD infection in the herd. Many of the cattle with DD had lesions concurrently in both hind feet during the current studies, well within the range of bilateral occurrence of 18 to $90 \%$ that was re- 


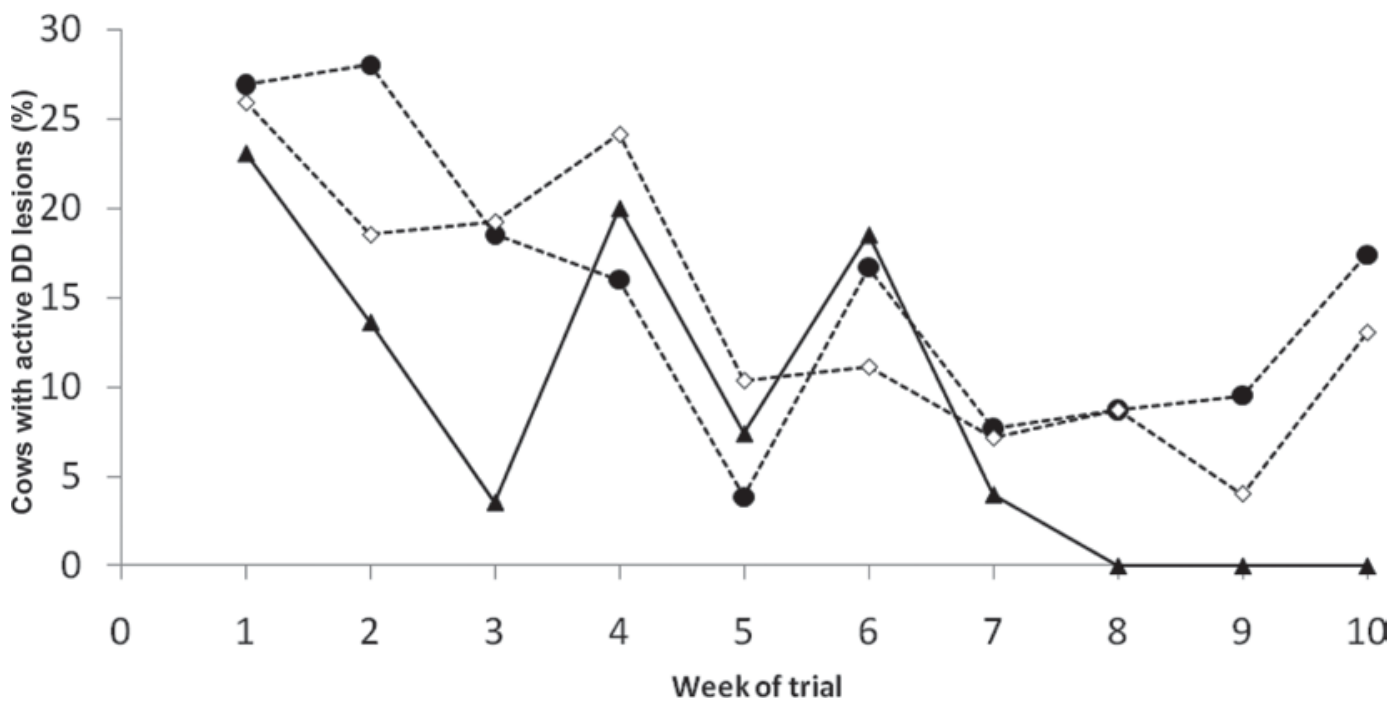

Figure 3. Percentage of cows with active digital dermatitis (DD) lesions (DD score in at least 1 hind foot) for footbath alternating between $5 \%$ copper sulfate $\left(\mathrm{CuSO}_{4}\right) 1$ wk and $10 \%$ salt water $(\mathrm{NaCl})$ every other week $(\mathbf{n}=28)$, footbath alternating between $5 \% \mathrm{CuSO}_{4} 1$ wk and tap water every other week $(\mathbf{\Delta} ; \mathrm{n}=28)$, and fortnightly footbath with $5 \% \mathrm{CuSO}_{4}(\diamond ; \mathrm{n}=29)$ in experiment 3.

ported previously (Nutter and Moffitt, 1990; Holzhauer et al., 2006; Holzhauer et al., 2008a).

Research has often used differing scoring systems and not all take into account the different stages of the disease (Koehorst, 2008), making comparisons of results difficult. In the current study, DD lesions were recorded using a standardized 5-stage scoring system outlined by Döpfer et al. (1997). The lesion sizes of DD stages M1 and M2 found in the current study support those of Holzhauer et al. (2008a). Yet, DD stages M3 and M4 were smaller and larger, respectively, than that found by Holzhauer et al. (2008a). The M3 lesion sizes ranged from $0.5 \mathrm{~cm}$ to $6.0 \mathrm{~cm}$, which was expected with lesions in different healing stages. Overall, the majority of DD lesions found were those of the "classical" ulcerative stage (M2). This clinical presentation appears typically seen in the UK and Europe (Laven, 2003; 2008). During the study DD lesions in the chronic (or proliferative) stage (M4) were observed and these were more commonly reported in the US (Laven, 2003; 2008). An unexpected increase in M4 lesions occurred, which were characterized as a chronic stage of lesion by dyskeratosis or proliferation of the surface toward the end of experiment 1 for the cows on the $\mathrm{CuSO}_{4}$ treatment. This may be because over a third of the cows on this treatment were brought in for embryo flushing. Severity of DD is affected by the same environmental factors as prevalence (Laven and Logue, 2007). Therefore, this may in part explain some of the increase in M4 lesions observed.

\section{Effect of Treatments on Digital Dermatitis}

Despite the high morbidity of DD, there is a lack of published peer-reviewed studies on the effectiveness of treatments; furthermore, the scope and design of the clinical trials that have been performed were not rigorously controlled (Vink, 2006). Group topical treatment; that is, walk-through footbaths, is often the only feasible option for treating DD on farms, but again conclusive data are lacking on the best treatment strategy (Laven, 2003).

Copper sulfate was the reference treatment chosen. This is because it appears to be the most commonly used nonantibiotic footbath solution besides formalin. In general, it is effective at concentrations of 2 to $8 \%$

Table 6. Proportional distribution of digital dermatitis (DD) lesion scores in hind feet in the different treatment groups at the start and end of experiment 3

\begin{tabular}{lcccc}
\hline & \multicolumn{3}{c}{ Treatment $^{2}$} \\
\cline { 2 - 4 } & $\begin{array}{c}\text { Salt } \\
\text { water }\end{array}$ & Water & Control & \multirow{2}{*}{ SED $^{3}$} \\
DD stage $^{1}$ & & & & \\
\hline M0 (no lesion) & $0.27^{\mathrm{b}}$ & $0.19^{\mathrm{a}}$ & $0.22^{\mathrm{ab}}$ & 0.038 \\
Start & $0.35^{\mathrm{b}}$ & $0.29^{\mathrm{ab}}$ & $0.26^{\mathrm{a}}$ & 0.038 \\
End & & & & \\
M2 (active) & 0.23 & 0.23 & 0.26 & 0.029 \\
Start & $0.17^{\mathrm{b}}$ & $0.00^{\mathrm{a}}$ & $0.13^{\mathrm{b}}$ & 0.029 \\
End & & & & \\
M3 (active) & 0.62 & 0.65 & 0.70 & 0.041 \\
Start & $0.52^{\mathrm{a}}$ & $0.71^{\mathrm{b}}$ & $0.65^{\mathrm{b}}$ & 0.041 \\
End & &
\end{tabular}

${ }^{\mathrm{a}, \mathrm{b}}$ Means within a row with different superscripts differ $(P<0.05)$.

${ }^{1} \mathrm{DD}$ stages: $\mathrm{M} 0=$ no lesion in both hind feet; $\mathrm{M} 2=$ classical ulcerative stage.M2 to M3 lesions in at least one hind foot.

${ }^{2}$ Treatments were as follows: salt water = alternating footbaths of $5 \%$ $\mathrm{CuSO}_{4}$ and salt water footbath on 4 consecutive milkings weekly $(\mathrm{n}=$ 28 ); water $=$ alternating footbaths of $5 \% \mathrm{CuSO}_{4}$ and tap water footbath on 4 consecutive milkings weekly $(\mathrm{n}=28)$; control $=5 \% \mathrm{CuSO}_{4}$ footbath on 4 consecutive milkings fortnightly $(\mathrm{n}=29)$.

${ }^{3}$ Standard error of the difference. 
(Laven and Hunt, 2002; Stevančević et al., 2009). The commercially recommended concentration of $\mathrm{CuSO}_{4}$ is 2.5 to $10 \%$, used weekly or fortnightly (Bishop, 2005; Klaas et al., 2008). Because it is considered to be an environmental hazard (Holzhauer et al., 2008b; Salam and El-Fadel, 2008) and is quite expensive (£0.20/d per cow at $5 \% \mathrm{CuSO} 4 \mathrm{X} 4 / 1 \mathrm{~W}$ ), the lower concentration of this range was used here. When compared with the negative control (no footbath), using $5 \% \mathrm{CuSO}_{4}$ after 4 consecutive milkings on a weekly basis was successful in reducing active DD lesions (M1 and M2) after 5 wk. It increased the number of cows with no or healing (M3) DD lesions. Furthermore, the results showed considerably more healing transition of lesions in this treatment compared with no footbath. Similarly, Stevančević et al. (2009) found that an $8 \% \mathrm{CuSO}_{4}$ solution used daily for $7 \mathrm{~d}$ had a curative effect that was similar to that of formalin but not as good as that of their positive control, the antibiotic chlortetracycline.

Laven and Hunt (2002) found that on a farm with mild endemic DD disease, daily footbaths for $7 \mathrm{~d}$ with a $2 \% \mathrm{CuSO}_{4}$ solution was as effective as a 2 -d treatment regimen with $0.0035 \mathrm{~g} / \mathrm{L}$ of the antibiotic erythromycin. This work was limited to 1 herd of cows and to a short period of treatment. Blowey and Sharp (1988) reported that using footbaths with low concentrations of $\mathrm{CuSO}_{4}(0.5$ to $2.5 \%)$ was ineffective. In the current study, a X4/1W footbath regimen with a $2 \% \mathrm{CuSO}_{4}$ solution was not as effective as a $5 \%$ solution. After 8 wk of footbaths, more cows had no DD lesions on the $5 \%$ versus the $2 \%$ weekly treatment and almost twice as many active M2 lesions were still present on the latter treatment. The $2 \% \mathrm{CuSO}_{4}$ footbath still reduced the proportion of active M2 lesions by more than half. After 8 wk of treatment, both the 2 and $5 \%$ weekly $\mathrm{CuSO}_{4}$ treatments had the same number of cows with DD lesions in the healing stage. Therefore, considering both treatments were applied to groups of cows that had a high DD prevalence ( 71 to $75 \%$ ), both methods can be considered effective, although to differing degrees.

A similar pattern was observed for $\mathrm{X} 4 / 2 \mathrm{~W} 2 \%$ and $5 \% \mathrm{CuSO}_{4}$ footbath treatments, in that more cows had no DD lesions at the end of the study period in the $5 \%$ versus the $2 \%$ treatment. Both of these treatments led to a reduction in active M2 lesions and an increase in healing M3 lesions after 8 wks of treatment. Milking machine wash water, or "parlor washings," was suggested as an alternative footbath solution (Laven and Logue, 2006). In the current study, a X4/1W $2 \%$ $\mathrm{ClO}^{-}$footbath solution was tested for 5 wk. The results did not confirm this as a useful treatment as the number of cows with active lesions increased toward the end of the experiment to the same extent as when the cows received no footbath at all. Similarly, for both the $\mathrm{ClO}^{-}$treatment and the control treatment, the healing transitions were considerably lower than that shown in the $5 \% \mathrm{CuSO}_{4}$ treatment. Boosman and Nemeth (1987) concluded that $\mathrm{ClO}^{-}$footbaths were ineffective in treating DD because the chemical loses its effectiveness in a dirty environment (i.e., in the presence of organic matter, such as slurry). da Silva et al. (2005) found that $\mathrm{ClO}^{-}$footbath solution was successful when the solution was changed after 120 cow passes or after $3 \mathrm{~d}$.

It was suggested that salt water, when used as a topical spray, could provide a cost-effective alternative to antibiotic use on farms as a preventative measure against DD (Ishmael et al., 2005). Salt is a common household antiseptic treatment that kills bacteria by dehydration (Matin et al., 2006). The efficacy of salt water as a footbath solution to help prevent or cure DD or both appears untested to date. In the current study, a final experiment investigated the use of a $10 \%$ salt solution as part of a footbath regimen. No significant advantage existed when using salt on alternating weeks when using a footbath regimen of $5 \% \mathrm{CuSO}_{4}$ fortnightly. A slight increase was observed in the number of cows with no lesions in the alternate salt water and $\mathrm{CuSO}_{4}$ treatment compared with control treatment, but that was offset by more cows having healing lesions in the latter treatment. Furthermore, using tap water in alternating weeks with $5 \% \mathrm{CuSO}_{4}$ led to an absence of cows with active M2 lesions at the end compared with the control and salt water treatments. This suggests that, despite similar healing transitions of the lesions, the water treatment may have been more effective.

\section{CONCLUSIONS}

On the basis of these results, we cannot recommend using a $2 \% \mathrm{ClO}^{-}$footbath solution as the sole method of treatment and control of a DD problem in a housed dairy herd; therefore, caution is needed when relying on parlor washings within a footbath regimen. Copper sulfate (2 to $5 \%$ ) can control DD, but it does not prevent new or reinfected DD lesions from occurring. In situations where the prevalence of DD is high, a weekly footbath routine using $5 \% \mathrm{CuSO}_{4}$ after 4 consecutive milkings was more effective than using a $2 \%$ solution. A fortnightly footbath routine, using $2 \% \mathrm{CuSO}_{4}$, can be used where prevalence of DD low, although cows must be monitored regularly for the disease. There appears to be no advantage to using a $10 \%$ salt water footbath solution in intervening weeks when a fortnightly $5 \%$ $\mathrm{CuSO}_{4}$ solution is used in the footbath. 


\section{ACKNOWLEDGMENTS}

The authors are indebted to the technicians and stockmen in the Dairy Unit of the Agri-Food and Biosciences Institute (Hillsborough, Northern Ireland) for their excellent technical assistance and care of the animals. Thanks are due to Dörte Döpfer (School of Veterinary Medicine, University of Wisconsin, Madison) and Nick Bell (Bristol University School of Veterinary Science, Langford, UK) for advice. The authors gratefully acknowledge AgriSearch and the Department of Agriculture and Rural Development for Northern Ireland for funding this project.

\section{REFERENCES}

Bishop, Y. M. 2005. The Veterinary Formulary. 6th ed. Pharmaceutical Press (in association with the British Veterinary Association), London, UK.

Blowey, R. 2007. Digital dermatitis-Research and control. Ir. Vet. J. $60: 102-106$.

Blowey, R. W., and M. W. Sharp. 1988. Digital dermatitis in dairy cattle. Vet. Rec. 122:505-508.

Boosman, R., and F. Nemeth. 1987. The detrimental effects of a sodium hydroxide standing footbath in cattle for the treatment of digital dermatitis (Mortellaro's disease). Tijdschr. Diergeneeskd. 112:1290-1293.

da Silva, L. A. F., C. A. Silva, J. R. J. Borges, M. C. S. Fioravanti, G. T. Borges, and I. B. Atayde. 2005. A clinical trial to assess the use of sodium hypochlorite and oxytetracycline on the healing of digital dermatitis lesions in cattle. Can. Vet. J. 46:345-348.

Döpfer, D., A. A. H. M. ter Huurne, J. L. Cornelisse, A. J. A. M. van Asten, A. Koopmans, F. A. Meijer, Y. H. Schukken, I. Szakall, W. Klee, and R. B. Bosma. 1997. Histological and bacteriological evaluation of digital dermatitis in cattle, with special reference to spirochaetes and Campylobacter faecalis. Vet. Rec. 140:620-623.

Esslemont, R. J. 2005. The costs of lameness in dairy herds. U.K. Vet. Livest. 10:41-49.

FAWC. 1997. Report on the welfare of dairy cattle. Farm Animal Welfare Council, Surrey, UK.

Holzhauer, M., C. J. M. Bartels, D. Döpfer, and G. van Schaik. 2008a. Clinical course of digital dermatitis lesions in an endemically infected herd without preventive herd strategies. Vet. J. 177:222230 .

Holzhauer, M., D. Doepfer, J. De Boer, and G. Van Schaik. 2008b. Effects of different intervention strategies on the incidence of papillomatous digital dermatitis in dairy cows. Vet. Rec. 162:41-46.

Holzhauer, M., C. Hardenberg, C. J. M. Bartels, and K. Frankena. 2006. Herd- and cow-level prevalence of digital dermatitis in the Netherlands and associated factors. J. Dairy Sci. 89:580-588.

IARC. 2006. Formaldehyde, 2-butoxyethanol and 1-tert-butoxypropan2-ol. Vol. 88. IARC Monographs on the Evaluation of Carcinogenic
Risks to Human. World Health Org., Int. Agency Res. Cancer, Lyon, France.

Ishmael, R., T. Goodman, J. Martin, and C. Stockwell. 2005. A comparison of the effectiveness of oxytetracycline or salt water in the management of digital dermatitis in dairy cattle. Page 207 in Proc. Br. Soc. Anim. Sci., York. Br. Soc. Anim. Sci., York, UK.

Klaas, I., K. Krogh, and J. T. Sorensen. 2008. The effect of two different footbath solutions on digital dermatitis. Pages 186-189 in Proc. 15th Intern. Symp. 7th Conf. Lameness Ruminants. Kuopio, Finland. Savonia University of Applied Sciences, Kuopio, Finland.

Koehorst, M. J. H. 2008. Literature study of Bovine Digital Dermatitis. PhD Thesis. Faculty of Veterinary Medicine, Utrecht University, the Netherlands.

Laven, R. A. 2003. Desktop review into the management and treatment of digital dermatitis. Technical Report No. 02/T3/07. Milk Development Council, Cirencester, UK.

Laven, R. A. 2008. Digital dermatitis: An update and an overview. Pages 4-22 in Proc. Cattle Consultancy Days 2008. Herning, Denmark.

Laven, R. A., and H. Hunt. 2002. Evaluation of copper sulphate, formalin and peracetic acid in footbaths for the treatment of digital dermatitis in cattle. Vet. Rec. 151:144-146.

Laven, R. A., and D. N. Logue. 2006. Treatment strategies for digital dermatitis for the U.K. Vet. J. 171:79-88.

Laven, R. A., and D. N. Logue. 2007. The effect of pre-calving environment on the development of digital dermatitis in first lactation heifers. Vet. J. 174:310-315.

Laven, R. A., and M. J. Proven. 2000. Use of an antibiotic footbath in the treatment of bovine digital dermatitis. Vet. Rec. 147:503506

Matin, A., S. V. Lynch, and M. R. Benoit. 2006. Increased bacterial resistance and virulence in simulated microgravity and its molecular basis. Gravit. Spac. Biol. 19:31-41.

Mitchell, G. B. B., and J. M. Law. 1984. Formaldehyde poisoning in cattle. Vet. Rec. 115:283-284.

Nutter, W. T., and J. A. Moffitt. 1990. Digital dermatitis control. Vet. Rec. 126:200-201.

Read, D. H., and R. L. Walker. 1998. Papillomatous digital dermatitis (footwarts) in California dairy cattle: Clinical and gross pathologic findings. J. Vet. Diagn. Invest. 10:67-76.

Rodríguez-Lainz, A., D. W. Hird, R. L. Walker, and D. H. Read. 1996. Papillomatous digital dermatitis in 458 dairies. J. Am. Vet. Med. Assoc. 209:1464-1467.

Salam, D., and M. El-Fadel. 2008. Mobility and availability of copper in agricultural soils irrigated from water treated with copper sulfate algaecide. Water Air Soil Pollut. 195:3-13.

Stevančević, M., B. Toholj, B. Lako, A. Potkonjak, and V. Kuljača. 2009. Study of the effectiveness of topical application of antiseptics in the therapy of digital dermatitis in diary cattle. Acta Vet.Beograd 59:437-445.

Vink, W. D. 2006. Investigating the epidemiology of Bovine Digital Dermatitis: Causality, transmission and infection dynamics. PhD Thesis. University of Liverpool, UK. 